\title{
The Arabic Script in Africa
}

The Arabic script's flexible and adaptive nature has made it a significant contributor to Africa's rich and vibrant socio-linguistic landscape. This has been noted by major scholars in the field, among them John Hunwick (director-general, Institute for the Study of Islamic Thought in Africa, Northwestern University, USA) and Helmi Sharawi (Centre for AraboAfrican Studies, Egypt). Meikal Mumin, a young German-Somali scholar who completed his M.A. at the University of Cologne's Institute for African Studies on the use of the Arabic script in Africa, solicited funds from the Fritz Thyssen Stiftung, as well as the necessary moral support from the above-mentioned institute, to host a workshop on this topic. Entitled "Arabic Script in Africa," it was held at the University of Koln's Institute for African Studies during 6-7 April 2010. Mumin regarded this event as the first of its kind on German soil to dealt with the "linguistic aspects of the usage and diffusion of the Arabic script in Africa for the writing of African languages, a phenomenon also known as Ajami." The assembled scholars investigated, among other concerns, linguistic, sociolinguistic, and historical processes as well as applied language policy for certain African languages.

Mumin, as the main coordinator along with Helma Pasch (University of Colonge), opened the workshop with his "The Arabic Script: Understudied Literacy." He raised several critical research questions, such as why and what were the consequences of the Arabic script in Africa being understudied, that stimulated and laid the event's foundations. Next came Peter Daniels, who analyzed "The Type and Spread of the Arabic Script" in West Africa. Nikolay Dobronravin (School of International Relations, St. Petersburg State University) focused on "West African Ajami in the New World 
(Hausa, Fulfulde, Mande Languages)" and Anneke Breedveld focused on "Ajami Manuscripts of Fulfulde Jihad Poetry from Yola" (Dutch Association of African Studies). Mumin stood in for Dobronravin, who was unable to make it.

Valentin Vydrin's (University of St. Petersburg) “Arabic-based Script for Manding Languages" stressed that the Mandinka Ajami was not standardized and argued that social science scholars have paid little attention to these texts. Andy Warren-Rothlin (Theological College of Northern Nigeria, and United Bible Societies), who elaborated further upon West African Ajami texts, stated in his "West African Ajami Orthographies in SocioPolitical Context" that the decreasing interest in using the Arabic script in Hausa, Fulfulde, and other languages may be attributed to the lack of standards and that attempts to standardize it may have inadvertently added to the problem.

Lameen Souag (SOAS, University of London) and Maarten Kossmann (University of Leiden) looked at the situation in North Africa. Souag's "Non-Arabic Arabic in Southwestern Algeria" explored what factors helped and guided Berber- and Songhay-speakers' orthographic decisions and to what degree they had devised new conventions. Kossmann's “Tuareg Ajami in its Regional Setting" highlighted that little research had been done concerning the orthographical practices employed for rendering Tuareg in the Arabic script and went on to talk about the choice of graphemes in the documents (e.g., letters, declarations, and theological manuscripts) that were studied.

The first day closed with Muhammed Haron (University of Botswana) and Kees Versteeg (University of Nijmegen), both of whom spoke on the use of "Arabic-Afrikaans" among the Cape Muslim community. From the respective titles of Haron's "Revisiting Al-Qawl al-Matin: A Carefully Crafted Socio-linguistically Engineered Arabic-Afrikaans Text" and Versteeg's "An Arabic-Afrikaans Grammar in the Arabic Script by Shaykh Ismail Edwards: 'Arabie fee loeghatiel 'arbie'," they discussed different aspects of this genre of literature that appeared in South Africa between the mid-nineteenth and mid-twentieth centuries.

The second day began Andreas Wetter's (Humboldt University, Berlin) "The Use of the Arabic Script for Ethiopian Languages." Bana Banafunzi (British Refugee Council) and Allessandra Vianello (independent researcher), who shared the platform with Wetter, voiced their thoughts about "Chimiini in the Arabic Script: Examples from the Poetry of Brava." They illustrated how the Brava community creatively adapted the script to 
catalogue their religious poetry in this Bantu vernacular in southern Somalia. Clarissa Vierke's (Bayreuth University) "Kala Shairi: Writing Swahili Poetry in Arabic Script," examined, among others issues, how this poetry was shaped by and shapes manuscript writing in East Africa. Xavier Luffin (Free University of Brussels) assessed "Swahili Documents from Congo (19th Century): Variation of Orthography" based on an array of collected letters and contracts to reveal the varieties of orthographies that emerged in the absence of standardization.

Mary-Eve Humery (IIAC-EHESS, Paris) discussed "A Case of Restricted Literacy: Writing in 'Ajami in the Haalpulaar Society of Fuuta Tooro (Senegal/Mauritania)." She prefaced her paper with a socio-linguistic context and examined the script's use in this Muslim-dominated region, where texts were not easily accessible and generally scarce. Mohammed Chtatou (ISESCO), used his "Using Arabic Script in Writing African Languages (by) Revisiting ISESCO's Experience 25 Years Later: Field Successes and Shortcoming" to overview ISESCO's ambitious cultural and educational undertakings, which began in the 1980s, and how it adopted a particular scientific methodology to implement its program and devise a standardized system for many African languages. He mentioned that since the organization issued its specially designed Arab-African typewriter to various institutions in different parts of Africa in 1994, many Ajami associations were formed to use the script in literacy and adult educational programs and health campaigns. According to him, Khartoum's International University of Africa is the only institution that offers an M.A. program on the Ajami script.

Each presentation raised many questions and significant discussions. Participants agreed to set up a TASIA Working Group via Facebook to initiate and sustain contact and work toward a follow-up workshop under the tentative title TAISA (The Arabic Script in Africa) Working Group, which for the moment was set up on Facebook (TAISA 2010). The group is thinking of coordinating and participating in (a) sociolinguistic and historical research and perhaps (b) acting as a consultative body for literacy projects in Africa. Everyone agreed that, under Mumin's academic leadership, the presentations should be revised, compiled, and published as an edited text. 